\title{
Improved Morphology and Biocompatibility of Chitosan/PEO Casting Films Adding Hyaluronic Acid
}

\author{
Hyaluronik Asit Ekleyerek Kitosan/PEO Döküm Filmlerinin \\ Morfolojisinin ve Biyouyumluluğunun İyileştirilmesi
}

\author{
Research Article \\ Esra Cansever Mutlü ${ }^{1 *}$ and Muhammet Yıldırım² \\ 'Scientific Industrial and Technological Application and Research Center, Bolu Abant Izzet Baysal University, Bolu, Turkey. \\ ${ }^{2}$ Department of Chemistry, Faculty of Arts and Sciences, Bolu Abant Izzet Baysal University, Bolu, Turkey.
}

\section{A B S TR ACT}

iopolymer-based blends can be used within the form of cast film in various proportions with polyethylene oxide (PEO) in order to obtain more durable and biocompatible surfaces. Chitosan and hyaluronic acid (HA) are the most used biocompatible biopolymers for the production of films. On the other hand, as a synthetic polymer, PEO has been mostly used to improve durability of the surfaces by using in various molecular weights. This study was carried out to determine the effect of HA on the chitosan and PEO biopolymer blends different from reported Chitosan/PEO film surfaces in the literature. FTIR studies presented no any polycationic amine groups belong to chitosan through the surface of four films in different compositions after casting. Surface morphology were determined by SEM, EDS and polarized microscopy analyses. Surface morphology was observed as well-oriented spherulitic crystallization by the increasing amount of PEO in the films. Astonishingly, it was proven that $\mathrm{HA}$ improved the biocompatibility feature of PEO-rich surfaces which were tested by using healthy mouse fibroblast cell lines, L929 (ATCC CCL-1).

\section{Key Words}

Biopolymer blends, chitosan, PEO, hyaluronic acid, film casting.

\section{öz}

iyopolimer esaslı harmanlar, polietilen oksit (PEO) ile daha dayanıklı ve biyouyumlu yüzeyler elde etmek için çeşitli oranlarda dökme film formunda kullanılabilir. Kitosan ve hiyaluronik asit (HA), film üretimi için en çok kullanılan biyouyumlu biyopolimerlerdir. Öte yandan, sentetik bir polimer olarak, PEO çeşitli molekül ağırIığında yüzeylerin dayanıkııığını arttırmak için çoğunlukla kullanılmaktadır. Bu çalışma, literatürde bildirilen Kitosan/PEO film yüzeylerinden farklı olarak, kitosan ve PEO biyopolimer karışımları üzerine, HA'nın etkisini belirlemek amacıyla yapılmıştır. FTIR sonuçları, farklı oranlarda dört filmin, yüzeyi boyunca kitosana ait herhangi bir polikatyonik amin grubunun dökümden sonra sunmamıştır. Yüzey morfolojisi SEM, EDS ve polarize mikroskop analizleri ile belirlenmiştir. Filmlerde artan PEO miktarı ile birlikte iyi yönlendirilmiş küresel kristalleşme yüzey morfolojisi gözlenmiştir. Şaşırtıcı olarak, HA'nın sağlıklı fare fibroblast hücre hattı, L929 (ATCC CCL-1) kullanılarak test edilen PEO bakımından zengin yüzeylerin biyouyumluluk özelliğini geliştirdiği kanıtlanmıştır.

\section{Anahtar Kelimeler}

Biyopolimer karışımlar, kitosan, PEO, hyaluronik asit, film döküm.

Article History: Received: Mar 28, 2018; Revised: Apr 2, 2018; Accepted: Jul 6, 2018; Available Online: Oct 4, 2018.

DOI: $10.15671 /$ HJBC.2018.243

Correspondence to: E. Cansever Mutlu, Sci. Ind. and Tech. App. and Res. Center, Bolu Abant Izzet Baysal University, Bolu, Turkey. 


\section{INTRODUCTION}

B iopolymer blend films have started to be used in many industrial areas by dint of expanding environmental awareness. These bio-based resources are aimed to be alternative to the conventional synthetic polymer blends for the many different industrial products [1,2]. Especially, the sugar-based polymers have many advantages for the replacement of synthetic polymers due to their low cost, non-toxicity, biodegradability and availability [3]. The one of them is cationic chitosan which is generally derived by a full or partial N-deacetylation of chitin which is obtained from exoskeleton of crustaceans as the one of the most abundant biopolymer in the nature [4]. Its copolymer structure composed of glucosamine and N-acetyl-glucosamine [5]. Chitosan has antibacterial, metal binding, mucoadhesive superior properties [6-8]. It is easily soluble in acid environment and can be used in gels, films, nanoparticle, patches, sutures, and fiber applications in various blend forms with other polymers [3,9].

The other valuable biopolymer, hyaluronic acid, of which biological functions have been pointed more and used in blends very recently [10-14]. It structurally consists of linear, N-acetyl-d-glucosamine and glucuronic acid chain [15]. Hyaluronic acid is the one of anionic glycosaminoglycans (GAGs) [10]. It has mostly found within extracellular matrix (ECM) and its astonishing viscoelastic property determines its polyelectrolyte characteristics $[11,16,17]$. Moreover, it can form polyelectrolyte complexes or multilayer structures with chitosan $[17,18]$. Hyaluronic acid has many functions in embryogenesis; such as, signal transduction, cell motility, cancer invasiveness, protecting delicate tissues and injured tissue surfaces [19].

Polyethylene oxide (PEO) is a colorless, semicrystalline, water-soluble, low toxic synthetic polymer. It is used with other biopolymers during the production of biological materials such as nano- or micro- films, spins, sprays and capsules [20-23]. It has flexible chain depending on the molecular weights that provide high viscosity and durability to the films [24]. It has flexible chain conformation due to molecular weight and this provides high durability within the films.
When they are used with biopolymers, especially chitosan, it can improve mechanical properties of cast film by the aid of chain conformation. Since, PEO has glassy physical characteristics, it can be generally used in making blend with other low durable biopolymers providing more flexibility to PEO. $[21,25,26]$.

In this study, it was investigated that the effect of hyaluronic acid within blends of Chitosan/PEO for four different proportions. As the investigating material, hyaluronic acid was set as $5 \% \mathrm{vv}^{-1}$ in each blend to form ternary blend. Changes in cast film surfaces were evaluated and its reflection to cell culture studies were carried out by using healthy mouse fibroblast cells, L929 cells and interpreted.

\section{MATERIALS and METHODS}

\section{Blend Preparation}

Blend composition of polymer films, Chitosan $120 \mathrm{~K}$ and degree of deacetylation 85\%; PEO 20K and Hyaluronic Acid $800 \mathrm{~K}$ were used. Four different polymer blend mixture (Film 1, Film 2, Film 3, Film 4) were prepared in $2 \%$ acetic acid $\mathrm{vV}^{-1}$ in $\mathrm{dd}$ water according to Chitosan/PEO ratio setting as 90:10\%, 80:20\%, 70:30\%, 60:40\%, respectively. Hyaluronic acid was added $5 \%$ in each blend composition. Total polymer amount was set 26.25 $\mathrm{mg} / \mathrm{mL}$. Prepared films were stirred during $18 \mathrm{~h}$ at room temperature. Clear polymer solutions were poured onto 60-mm-diameter polystyrene Petri dishes immediately after degassing. Solvent was slowly evaporated at room temperature. Finally, the blends were kept in a vacuum oven for 4 days at $40^{\circ} \mathrm{C}$ to remove traces of water and acetic acid. Thickness of films was found to be in the range of $75 \pm 5 \mu \mathrm{m}$.

\section{FTIR Studies}

FT-IR spectra of the blends were recorded on a Shimadzu 8400S FT-IR spectrophotometer. Measurements were conducted between 600$4000 \mathrm{~cm}^{+1}$ in transmission mode. FT-IR images were taken by using directly or by embedding the films in $\mathrm{KBr}$ pellets.

\section{SEM and EDS Analysis}

The prepared blend films were cut as $2 \mathrm{~cm}^{2}$. Then, they are put on metal grids with double 
sided adhesive carbon tape, coated with gold to $\sim 500 \times 10^{-8} \mathrm{~cm}$ in thickness using sputter coater under high vacuum, $0.1 \mathrm{Torr}, 1.2 \mathrm{kV}$, and $50 \mathrm{~mA}$ at $27 \mathrm{C} \pm 1 \mathrm{C}$. The surface morphology of coated samples was evaluated by scanning electron microscopy 20.000X magnification of SEM; and EDS (JEOL JSM Tokyo, Japan) at $20 \mathrm{kV}$.

\section{Polarized Light Microscopy Analysis}

Four different blends were observed under light microscopy with using polarized attachment of Olympus BX53. All images were recorded by $40 X$ magnification at room temperature.

\section{In vitro Cell Culture Studies}

Sterilization of all blend films was performed under UV light during 6 hour. The mouse fibroblast cell lines, L929 (ATCC number CCL1) were obtained from Marmara University Department of Bioengineering and cultured in DMEM supplemented with $10 \%$ FCS, $1 \%$ Glutamax $50 \mathrm{U}$. $\mathrm{mL}^{-1}$ penicillin, and $50 \mathrm{mg} \mathrm{mL}^{-1}$ streptomycin (Gibco). Casting films were fixed into each well as 5 $\mathrm{mm}$ by selfadhesion to bottom. Immediately after fixed films were subjugated UV light within sterile laminar flow hood approximately $1 \mathrm{~h}$. Cultured cells during 3 days in a $5 \% \mathrm{CO}_{2}$ humid atmosphere at $37^{\circ} \mathrm{C}$ were used for cell culture studies by seeding into each sample in 96-well plates at a density of $2.1 \times 10^{4}$ cells in the per well. After incubated for 72 h, MTT Assay (CellTiter 96 aqueous one solution cell proliferation assay kit from Promega) were tested to measure cell proliferation of film samples. Plates were applied to measured the optical density at $570 \mathrm{~nm}$ of cells at $37^{\circ} \mathrm{C}$ by using ELISA Reader. Samples were tested in triplicate, and results were showed as the average of the measured values. The absorbance values are proportional to the number of metabolically active cells on the surface of biomaterials. Control cells were considered according to their viability. Statistical analyses were performed by one way ANOVA.

\section{RESULTS and DISCUSSION}

\section{FTIR Studies}

Four polymer blends were prepared in different compositions of chitosan/PEO/HA and characterized by FT-IR analyses (Figure 1). In IR spectra of four blend films, $\mathrm{OH}$ stretchings of chitosan and of HA (3473-3381 $\left.\mathrm{cm}^{-1}\right)$ appeared as mixed broad absorption peaks in $80 / 20$ and $70 / 30$ blend compositions but corresponding $\mathrm{OH}$ stretchings of $90 / 10$ and $60 / 40$ blend films were observed as less broader peaks at lower wavenumbers $\left(3452,3414 \mathrm{~cm}^{-1}\right)$. These broad absorptions and slight shifts can be the evidences for the presence of hydrogen-bonding interactions in corresponding blends. $\mathrm{C}=\mathrm{O}$ stretching band of pure chitosan at $1660 \mathrm{~cm}^{-1}$ shifted slightly to lower wavenumbers $\left(1653-1641 \mathrm{~cm}^{-1}\right)$ in all blends. Similarly, NH bending absorption peak of pure HA (1616-1620 and $\left.1458 \mathrm{~cm}^{-1}\right)$ shifted to lower wavenumbers $\left(1570-1558 \mathrm{~cm}^{-1}\right)$ in all blend compositions. Increases in $\mathrm{CH}_{2}$ bending band intensities of PEO (1469-1456, 1280, $\left.1242 \mathrm{~cm}^{-1}\right)$ were also observed by increasing amounts of PEO in 80:20, 70:30 and 60:40 blends. However, $\mathrm{CH}_{2}$ bending band intensity of chitosan $\left(1379,1321 \mathrm{~cm}^{-1}\right)$ was dominant in only 90:10 blend. Besides, C-O-C stretching bands of chitosan appeared at 1095 $\mathrm{cm}^{-1}$ as dominant band in 90:10 blend composition, but $\mathrm{C}-\mathrm{O}-\mathrm{C}$ stretching bands of PEO appeared at $1041 \mathrm{~cm}^{-1}$ as dominant band in only 60:40 blend composition by increasing amount of PEO. In all blends, C-O-C absorption bands of HA mostly coincided with the $\mathrm{C}-\mathrm{O}-\mathrm{C}$ bands of chitosan and of PEO at around 1095-1022 $\mathrm{cm}^{-1}$.

Our results are in accordance with Zivanovic and coworkers' results [25]. Furthermore, in another study, Eroğlu and coworkers evaluated FT-IR spectra ternary blend film chitosan/PEO/ Levan. This study indicated the chitosan and levan suppressed the PEO crystallinity that changed physicochemical properties of blend films [21]. Also, our results confirmed the same tendency of chitosan and hyaluronic acid within Film 4 which move to the top side of the surface.

\section{SEM and EDS Analysis}

SEM images were obtained for four different blend films (Figure 2). SEM images clearly indicated that the Film1 has the smoothest surface depending on the increased amount of Chitosan (A). By increasing the ratio of PEO in blend film, surface seemed more indented as indicated in SEM image of Film2 (B). However, the SEM image (C) proved the crystalline surface of Film3 (Ch/PEO: 70/30). Kit and coworkers showed ultra-thin film blends even in low molecular weight chitosan $(\$ 150 \mathrm{kDa})$ 


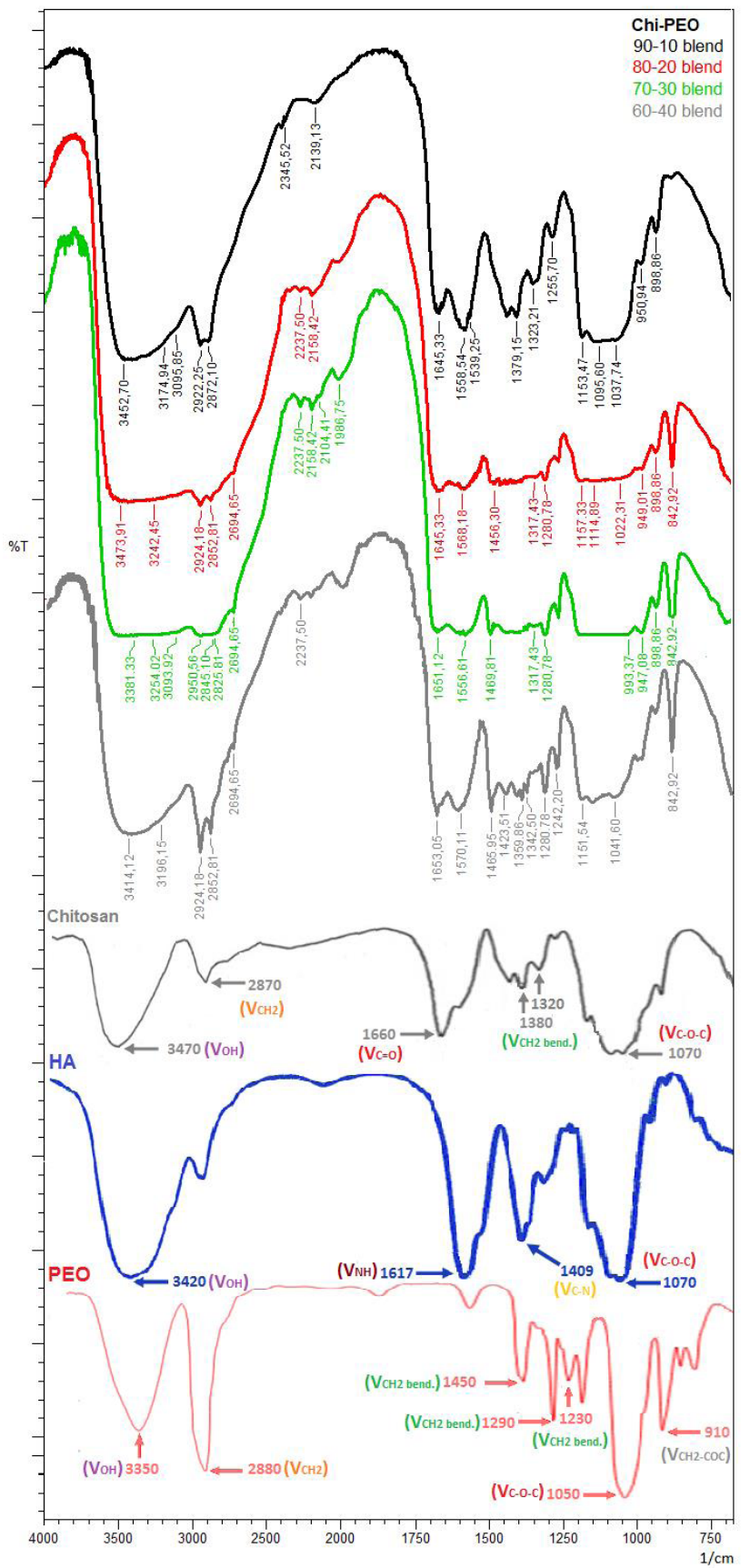

Figure 1. Characterization of FTIR Spectra of Chitosan/PEO/HA Blends (4000-600 $\left.\mathrm{cm}^{-1}\right)$. Chitosan/PEO ratio: Film1 (90/10); Film2 (80/20); Film3 (70/30); Film4 (60/40).

and high molecular weight PEO (900 kDa), 10\% chitosan in blend increased surface roughness [27]. In our study, it was achieved the formation of smoother and regular indented surface as regular layers by the composition of Film4, even if the amount of PEO has been increased. This evidence proved that hyaluronic acid provides more homogenous environment in Film4 between chitosan and PEO.
Energy-dispersive $\mathrm{X}$-ray photoelectron spectroscopy (EDS) results of polymer blends were analyzed to ensure the elemental composition of blends. Surface of films were essentially consisted of carbon and oxygen. It wasn't observed any other sharp electron diffraction ring that implies other group on the surface for each film. The results verified the similar amount of components 
A

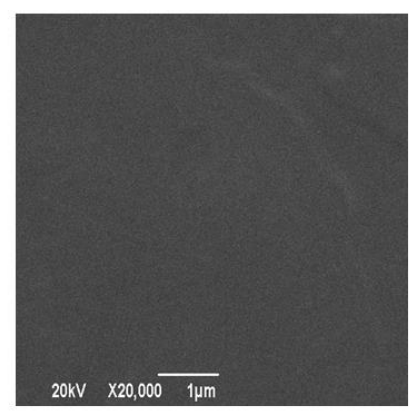

C

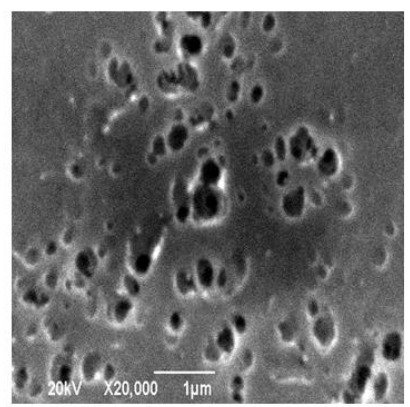

B

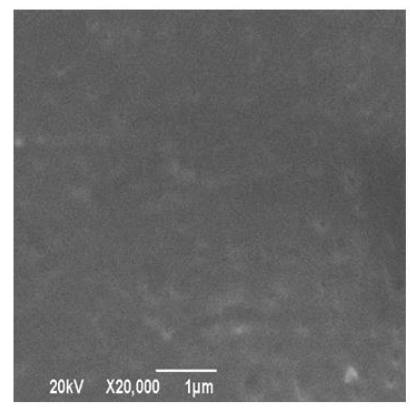

D

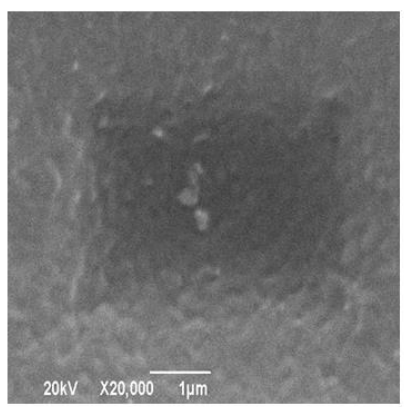

Figure 2. SEM image of (A) Film 1: smooth chitosan surface, (B) Film2: intended chitosan surface, (C) Film3: crystalize surface, (D) Film4: smooth intended miscible chitosan/PEO/HA surface under 20.000X magnification.

on the selected area of blend films (Film1-4). However, Film4 has the highest amount of carbon groups and the least amount of oxygen groups (Table 1). When the amount of PEO increased from Film 1 to Film 4, the number of oxygen groups in blends decreased. On the contrary, the number of carbon groups in blends increased on the surface of films. These results supported FT-IR spectra and surface analysis of film blends.

\section{Polarized Microscopy Measurements}

Film blends were evaluated by using polarized microscope with a $40 \mathrm{X}$ magnification in order to observe crystalline regions, thereof semicrystalline PEO chains (Figure 3). All the films were transparent and slightly yellowish in color and PEO changed the physicochemical structure of blend mixtures. Film1 had no crystalline region in $90 / 10$ blend ratio due to higher amount of chitosan which suppresses the spherulitic growth of PEO crystals (Figure 3-A). With the small increase in amount of PEO in Film2 (80/20), some of the monoclinic crystals of PEO chains has started to form (Figure $3-\mathrm{B}$ ). By increasing the amount of PEO in 70/30 blend ratio, the spherulitic formation of monoclinic PEO crystals has increased further on the surface of Film3 (Figure 3-C). However, the greatest extent of spherulitic PEO crystal formation were obviously seen on the film4 surface (60/40) (Figure 3-D). Besides, the similar investigations with the increased ratio of PEO more than $50 \%$ in the films indicated the formation of colorless films and increased amount of chitosan in PEO blend films reduce the PEO spherulitic crystallization of PEO chains $[25,27]$. Thereby, our findings on PEO crystal formation are coherent with the results of biopolymer blend film studies in the literature.

\section{In vitro Cell Culture Studies}

Cell viability tests were performed to investigate the effect of hyaluronic acid on the cell proliferation of mouse fibroblast L929 on the cell surface for 72 hour. The cells in direct interaction with Film1, Film2, Film3 and Film4 were subjugated to MTT assay. Control cells were $100 \%$ viable. All films were highly biocompatible even after 72 hour. All the cell viabilities increased (Film1: 473\%, Film 2: 1204\%, Film 3: $1297 \%$ and Film 4: 1603\%) by the decreasing amount of PEO and increasing amount of chitosan. However, Film4 has induced the maximum cell proliferation. This evidence 
Table 1. EDS results of surface components (Carbon, Oxygen and Hydrogen) of films; the Chitosan/PEO ratio Film1 (90/10); Film2 (80/20); Film3 (70/30); Film4 (60/40).

\begin{tabular}{llll}
\hline Surface Component & C wt.\% & O wt.\% & H wt.\% \\
\hline Film 1 & 50.76 & 49.23 & 0.00 \\
\hline Film 2 & 52.27 & 47.73 & 0.00 \\
\hline Film 3 & 52.78 & 47.22 & 0.00 \\
\hline Film 4 & 56.77 & 43.23 & 0.00 \\
\hline
\end{tabular}

A

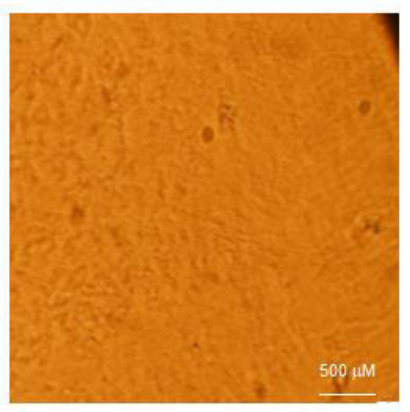

C

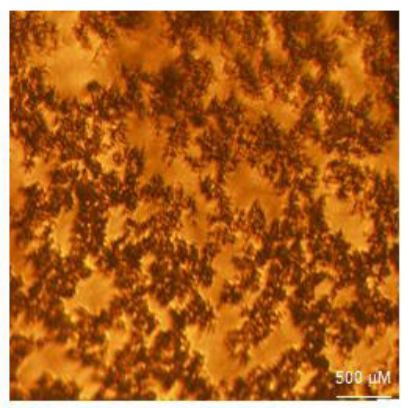

B

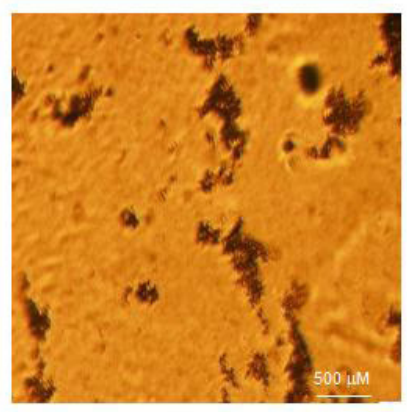

D

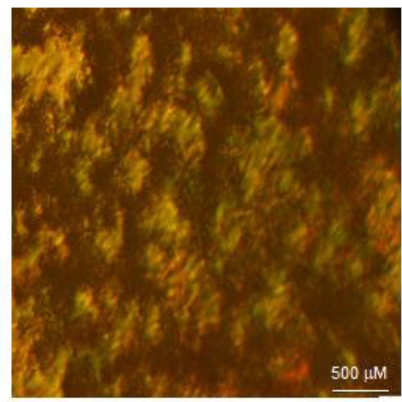

Figure 3. Polarized optical microscope images under 40X of (A) Film1; (B) Film2; (C) Film3; (D) Film4.

showed that the hyaluronic acid maintain miscibility of chitosan and PEO in 60/40 ratio. Film4 displayed good adherent morphology as in the SEM images (Figure 2D) for the attachment and proliferation of $L 929$ cells. In fact, it is the other evidence as Zhao and coworkers indicated that good miscibility is closely related to good biocompatibility. While the amount of chitosan is nearly $50 \%$ or less, the miscibility and biocompatibility increase [28].

\section{CONCLUSION}

This study proved that hyaluronic acid has changed physicochemical and biological characterization of chitosan/PEO/hyaluronic acid blend films. The well-oriented spherulitic PEO crystallization was clearly observed on the surface of Film4 through the 40X polarized microscopy images. Similarly, Kit and coworkers showed that the spherulitic crystallization was dominant in each film by an increase only in the amount of PEO in Chitosan/ PEO blend films (over 80/20) in 100X polarized microscopy studies [25]. SEM and EDS analyses showed that the PEO enrichment provided a reliable direction of radial crystallization on the surface depending on the ratio of chitosan/PEO/ hyaluronic acid 57.1/38.1/4.8 (v/v\%) in Film4. Cell viability and proliferation studies were performed by using mouse fibroblast L929 cells on four 


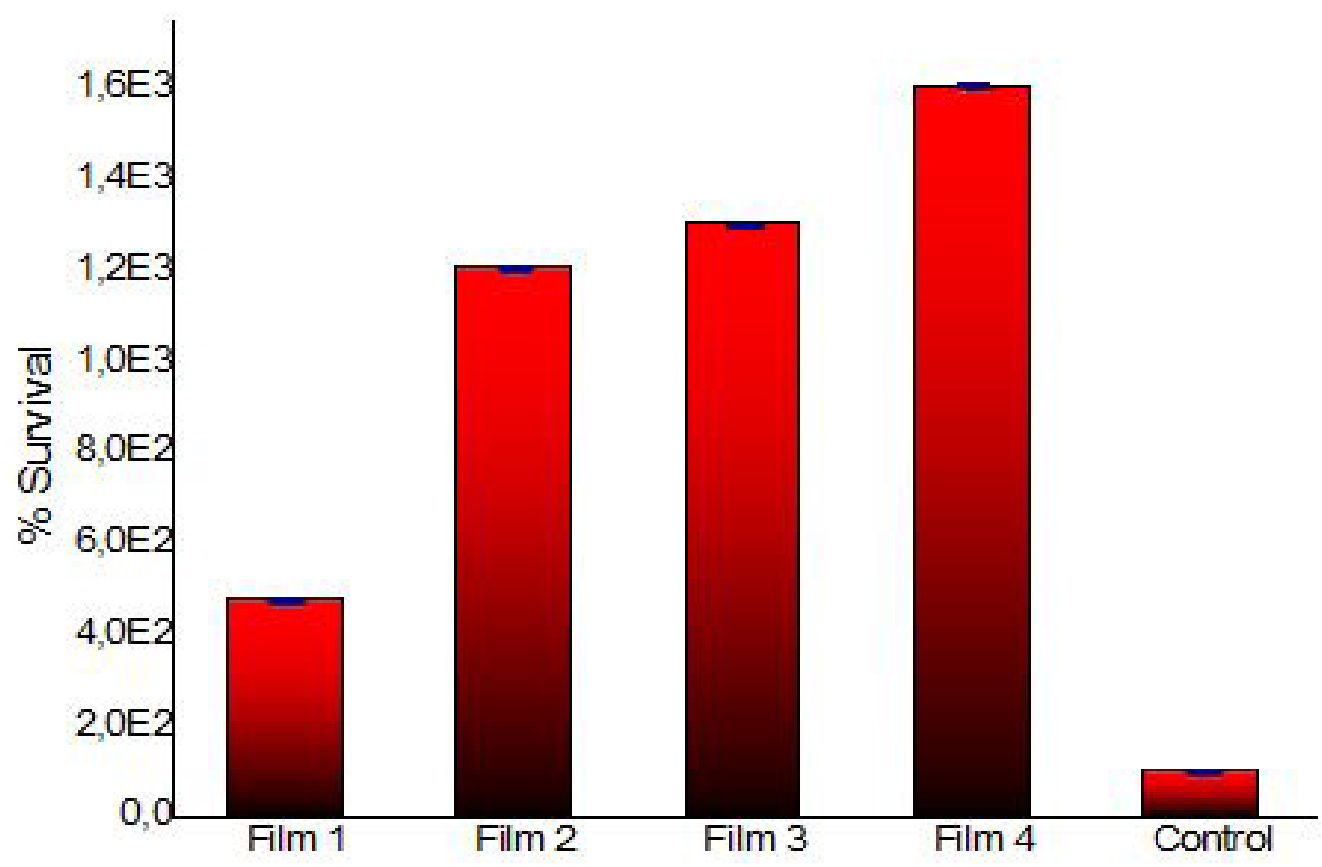

Figure 4. Cell viability of L929 cells after being cultured with the blend films; Film1, Film2, Film3, Film4 after 72 h.

different content of polymer film surfaces. Even after 72 hour, no toxicity was observed for each film. L929 cells clearly achieved attachment and proliferation onto all films via performing their normal adherent morphology; in which, all were higher than control group. However, by increased amount of PEO and decreased amount of chitosan from Film 1 to 4 , the biocompatibility has increased. On the contrary, in the another study, pure chitosan /PEO films in 70/30 and 60/40 ratios affected the viability of mouse fibroblast cells, L929 (CCL-1) after $24 \mathrm{~h}$, the viabilities were below $50 \%$ depending on increasing amount of PEO [21]. It is evident from the results that hyaluronic acid chains provide not only good entanglement between chitosan and PEO; but also, serve as the best three dimensional vicinity with high molecular weight chitosan for cells to adhere for proliferation.

\section{Acknowledgements}

Authors thanks to Bolu Abant Izzet Baysal University Scientific Research Funds through BAP Project
No:2018.03.03.1295.

\section{References}

1. P. Fajardo, J. Martins, C. Fuciños, L. Pastrana, J. Teixeira, and A. Vicente, Evaluation of a chitosanbased edible film as carrier of natamycin to improve the storability of Saloio cheese, J. Food. Eng., 101 (2010) 349-356.

2. M. Syakir, N. Nurin, N. Zafirah, M. A. Kassim, and H. A. Khalil, Nanoclay reinforced on biodegradable polymer composites: potential as a soil stabilizer, in nanoclay reinforced polymer composites, (2016), Springer. 329-356.

3. M.S. Eroglu, E. Toksoy Oner, E. Cansever Mutlu, and M. Sennaroglu Bostan, Sugar based biopolymers in nanomedicine; new emerging era for cancer imaging and therapy, Curr. Top. Med. Chem., 17 (2017) 15071520.

4. F. Al Sagheer, M. Al-Sughayer, S. Muslim, and M. Z. Elsabee, Extraction and characterization of chitin and chitosan from marine sources in Arabian Gulf, Carbohyd. Polym., 77 (2009) 410-419.

5. R.C.F. Cheung, T.B. Ng, J.H. Wong, and W.Y. Chan, Chitosan: an update on potential biomedical and 
pharmaceutical applications, Mar. Drugs., 13 (2015) 5156-5186.

6. A. Varma, S. Deshpande, and J. Kennedy, Metal complexation by chitosan and its derivatives: a review, Carbohyd. Polym., 55 (2004) 77-93.

7. E. Guibal, T. Vincent, and R. Navarro, Metal ion biosorption on chitosan for the synthesis of advanced materials, J. Mater. Sci., 49 (2014) 5505-5518.

8. I.A. Sogias, A.C. Williams, and V.V. Khutoryanskiy, Why is chitosan mucoadhesive?, Biomacromolecules, 9 (2008) 1837-1842.

9. M.S. Bostan, M. Senol, T. Cig, I. Peker, A. C. Goren, T. Ozturk, and M. S. Eroglu, Controlled release of 5-aminosalicylicacid from chitosan based $\mathrm{pH}$ and temperature sensitive hydrogels, Int. J. Biol. Macromol., 52 (2013) 177-183.

10. T. Noguchi, B. Roy, D. Yoshihara, J. Sakamoto, T. Yamamoto, and S. Shinkai, Emergent molecular recognition through self assembly: unexpected selectivity for hyaluronic acid among glycosaminoglycans, Angewandte Chemie International Edition, 55 (2016) 5708-5712.

11. M.N. Collins and C. Birkinshaw, Hyaluronic acid based scaffolds for tissue engineering-A review, Carbohyd. Polym., 92 (2013) 1262-1279.

12. K. Lewandowska, A. Sionkowska, S. Grabska, and B. Kaczmarek, Surface and thermal properties of collagen/hyaluronic acid blends containing chitosan, Int. J. Biol. Macromol., 92 (2016) 371-376.

13. K. Lewandowska, A. Sionkowska, and S. Grabska, Chitosan blends containing hyaluronic acid and collagen. Compatibility behaviour, J. Mol. Liq., 212 (2015) 879-884.

14. L. Mayol, D. De Stefano, F. De Falco, R. Carnuccio, M. C. Maiuri, and G. De Rosa, Effect of hyaluronic acid on the thermogelation and biocompatibility of its blends with methyl cellulose, Carbohyd. Polym., 112 (2014) 480-485.

15. N.V. Rao, H.Y. Yoon, H.S. Han, H. Ko, S. Son, M. Lee, H. Lee, D.G. Jo, Y.M. Kang, and J.H. Park, Recent developments in hyaluronic acid-based nanomedicine for targeted cancer treatment, Expert. Opin. Drug. Del., 13 (2016) 239-252.

16. J.P. Berezney and O.A. Saleh, Electrostatic effects on the conformation and elasticity of hyaluronic acid, a moderately flexible polyelectrolyte, Macromolecules, 50 (2017) 1085-1089.

17. G. Lalevée, G. Sudre, A. Montembault, J. Meadows, S. Malaise, A. Crépet, L. David, and T. Delair, Polyelectrolyte complexes via desalting mixtures of hyaluronic acid and chitosan-Physicochemical study and structural analysis, Carbohyd. Polym., 154 (2016) 86-95.

18. N. E. Muzzio, M. A. Pasquale, E. Diamanti, D. Gregurec, M. M. Moro, O. Azzaroni, and S. E. Moya, Enhanced antiadhesive properties of chitosan/hyaluronic acid polyelectrolyte multilayers driven by thermal annealing: Low adherence for mammalian cells and selective decrease in adhesion for Gram-positive bacteria, Mater. Sci. Eng. C, 80 (2017) 677-687.

19. G. Kogan, L. Šoltés, R. Stern, and P. Gemeiner, Hyaluronic acid: a natural biopolymer with a broad range of biomedical and industrial applications, Biotechnol. Lett., 29 (2007) 17-25.

20. J. D. Đoki , A. Kojovi , D. Stojanovi , A. Marinkovi , G. Vukovi，R. Aleksi, and P. S. Uskokovi, Processing and nanomechanical properties of chitosan/ polyethylene oxide blend films, J. Serb. Chem. Soc., 77 (2012) 1723-1733.

21. M. S. Bostan, E. C. Mutlu, H. Kazak, S. S. Keskin, E. T. Oner, and M. S. Eroglu, Comprehensive characterization of chitosan/PEO/levan ternary blend films, Carbohyd. Polym., 102 (2014) 993-1000.

22. H. Wang, J. K. Keum, A. Hiltner, E. Baer, B. Freeman, A. Rozanski, and A. Galeski, Confined crystallization of polyethylene oxide in nanolayer assemblies, Science, 323 (2009) 757-760.

23. T. Doussineau, M. Kerleroux, X. Dagany, C. Clavier, M. Barbaire, J. Maurelli, R. Antoine, and P. Dugourd, Charging megadalton poly(ethylene oxide)s by electrospray ionization. A charge detection mass spectrometry study, Rapid. Commun. Mass. Sp., 25 (2011) 617-623.

24. V. Guarino, M. Marrese, and L. Ambrosio, Chemical and physical properties of polymers for biomedical use, in advanced polymers in medicine. (2015), Springer. 67-90.

25. S. Zivanovic, J. Li, P.M. Davidson, and K. Kit, Physical, mechanical, and antibacterial properties of chitosan/ PEO blend films, Biomacromolecules, 8 (2007) 15051510.

26. S. Bonardd, M. Schmidt, M. Saavedra-Torres, A. Leiva, D. Radic, and C. Saldías, Thermal and morphological behavior of chitosan/PEO blends containing gold nanoparticles. Experimental and theoretical studies, Carbohyd. Polym., 144 (2016) 315-329.

27. J. Li, S. Zivanovic, P. Davidson, and K. Kit, Production and characterization of thick, thin and ultra-thin chitosan/PEO films, Carbohyd. Polym., 83 (2011) 375382.

28. W. Zhao, L. Yu, X. Zhong, Y. Zhang, and J. Sun, The compatibility and morphology of chitosan-poly (ethylene oxide) blends, J. Macromol. Sci. B., 34 (1995) 231-237. 